\title{
Firm size and solvency in Indian pharmaceutical sector: A relational co-movement analysis
}

\author{
Anis Ali ${ }^{\text {* }}$

\begin{tabular}{l}
\hline C H R O N I C L E \\
\hline Article history: \\
Received: July 28, 2020 \\
Received in revised format: \\
July 302020 \\
Accepted: September 6, 2020 \\
Available online: \\
September 7, 2020 \\
\hline Keywords: \\
Firm size \\
Solvency \\
Indian pharmaceutical \\
Rank correlation \\
Long-term debts \\
Total assets \\
Owners' equity
\end{tabular}

${ }^{a}$ Department of Management, College of Business Administration, Prince Sattam Bin Abdulaziz University, Al kharj- 11942, Saudi Arabia A B S T R A C T

\begin{abstract}
The financial size of the firm can be defined based on sales, working capital (WC), and total assets of the business organization. Two terms i.e. liquidity and solvency are to be used to measure the paying ability of the business. The liquidity is a short-term approach while solvency is the long-term approach of redemption of long-term debts (LTDs). The study investigates the relationship between size determinants and solvency of the Indian pharmaceutical business organization as few studies available that explain the relationship between the size of the firm and solvency in the pharmaceutical industry. The study considers the data of the selected pharmaceutical companies in India for the period 2013-2018. Two approaches are to be used to analyze the solvency i.e. solvency against ownership and solvency against the total assets (TA). Ratio analysis is the basis of the study and Spearman's rank correlation is calculated to get the relative relationship between size and solvency of the Indian pharmaceutical companies. The result of the relative study shows the positive and moderate correlation between the size determinants and solvency of the Indian pharmaceutical companies.
\end{abstract}

\section{Introduction}

There are two terms liquidity and solvency used to measure the paying ability of the business organizations. Liquidity refers to the short-term paying ability while solvency is associated with the redemption of long-term debts or liabilities of the business organization. In other words, the short-term paying ability refers to the operational payment while solvency reveals the payment of non-operational items, contractual capital, or any other extraordinary liabilities payable after an accounting period. The paying ability of the business organization depends on many factors i.e. factors responsible for the short-term paying ability and longterm paying ability. The short-term paying ability factors are closely related to the velocity of the cash conversion cycle or cash conversion period that starts from the introduction of the cash for operational activities and ends with the cash sales or collection form accounts receivables. The liquidity of the business organization to payout short-term liabilities will be enough, if the cash cycle period of operational activities is smaller, collection from the accounts receivables is faster and payment to the creditors are comparatively slow. This process makes available more current assets (CA) and especially cash or cash equivalent for making payment of the current liabilities (CL). So, the short-term paying ability is necessary for the smooth operation of business activities. The long-term paying ability of the business depends on the capital structure or the capital composition of the business and total debt to total assets ratio. The capital composition refers to the ratio between the total debt and owners' equity while the total debt (TD) to total assets (TA) ratio refers to the ratio between long term debt (LTD) and total assets (TA) or resources

* Corresponding author

E-mail address: ah.ali@psau.edu.sa (A. Ali) 
of the business. A lower capital structure or debt-equity ratio, and total debt (TD) to total assets (TA) ratio is an indication of the sound solvency of the business organization. But, the higher the solvency ratio is the worse the status of working on equity. So, there should be an optimum balance between total debt (TD) and owners' equity to maintain the solvency and return for owners' point of view. Also, the lower debt to assets ratio indicates that the total resources are arranged from the owners' fund, not from LTD, and reflect the sound financial position. The financial size of the firms is determined by the three variables i.e. sales, totals assets (TA), and working capital (WC) (Ali, A., 2020a). Sales of the goods and services of the business organization refer to the level of operational activities while the WC and TA indicate the resources available to run the operational activities. The sales amounts reflect the involvement of the employees and resources needed to procure the factors of production to fulfill the demand of the product on the market. To study the relationship between the firms' size and solvency, the analysis of sales, WC, TA, LTD, and owners' equity of the business organization is necessary. Fig. 1 explains the absolute amount and trend of the size determinants, LTD, and owners' equity of the selected leading pharmaceutical companies of India.

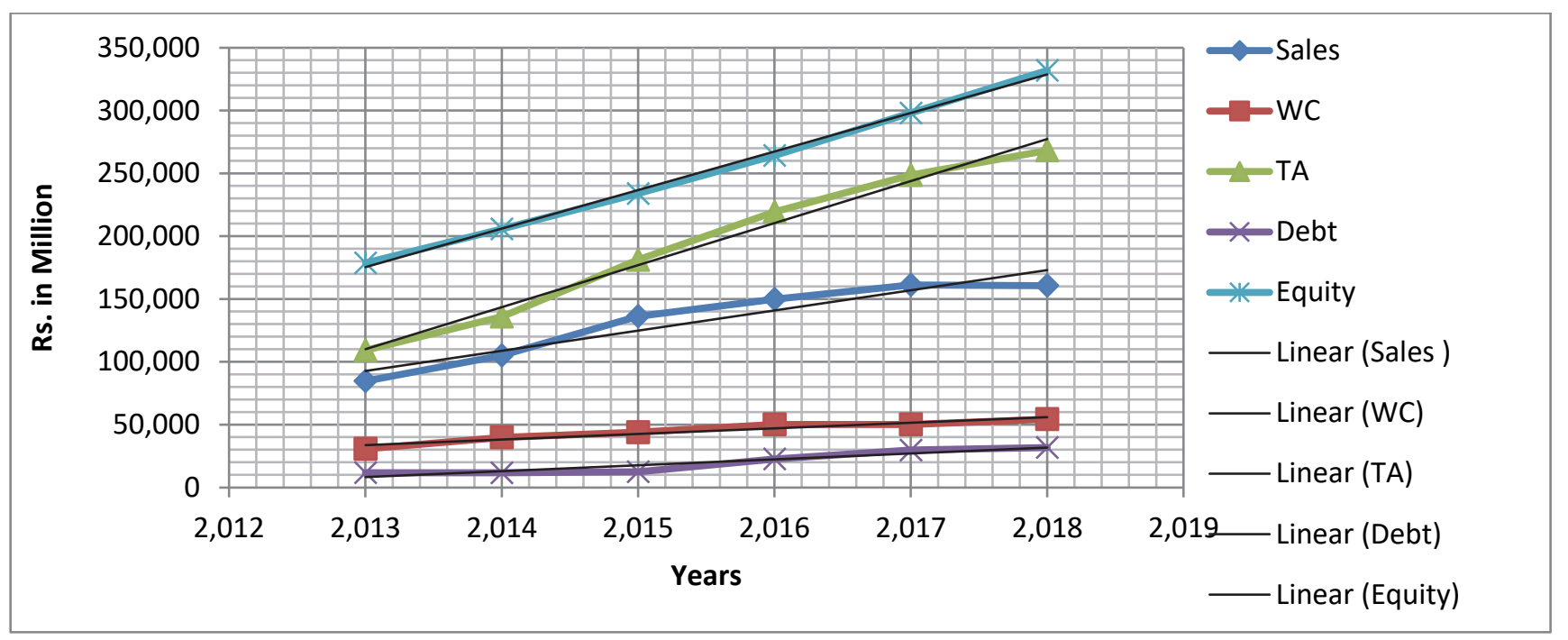

Fig. 1. Trend of average absolute amounts of size determinants (sales, WC, and TA), LTD \& Equity of Indian pharmaceutical companies

From the above figure, it can be explained that there is a very low ratio between the debt and equity, and debt and total assets. There is a huge difference between the internal capital (owners' equity) and external capital (debt), and TA and debt. This reveals the sound financial position or the solvency of the selected leading Indian pharmaceutical companies. The increasing trend of the equity, total assets indicates the sound financial position of the Indian pharmaceutical sector. The size determinants (sales, WC, and TA), and solvency proxies (TA, TD, and owners' equity) are increasing but the increasing trend on the size determinants are not perfectly support solvency proxies. There are no studies available that explain the relationship between the firms' size and solvency of Indian pharmaceutical companies. So, there is a requirement to find and establish an average relationship between size determinants and solvency proxies of the Indian pharmaceutical companies.

\section{Literature review}

Dang et al. (2018) suggested that the firm size variable is the robust variable to measure and basis for all aspects of corporate finance. Nair (2013) found that gross earnings govern the solvency of the firm. Mutiara et al. (2018) revealed that the size of the form has a relatively negative impact on the financial performance of the firm. Saragih (2019) found the effect of the firm size on audit delay while solvability has a significant effect on audit delay. But he did not study the firm size and solvency. Marjohan et al. (2019) observed in their study that firm size and solvency positively influence profitability. The size of the firm and financial performance has a negative impact on financial soundness (Lopez-Valeiras et al., 2016). The total assets are not the only means of measuring the size of the firm while the number of employees and the market value of the firm is also considerable factors (Huff et al., 1999). Muhindi and Ngaba (2018) found in their study that the size of the firm has a positive impact on the financial performance of banks in Kenya. The large banks financially perform better than small or medium banks. Ayuba et al. (2019) recommended that the firm should increase its total assets to increase its size by issuing the debts. Ultimately, it will reduce the ratio of owners' capital in the firm. González and González (2011) suggested that both theory i.e. TOT (tradeoff theory) and POT (pecking order theory) are suitable to enhance the size of the firm but a negative relationship with the profitability especially in smaller and medium firms. The Fixed Assets to Total Assets and firms' size affect the profitability on 
total assets, insignificantly (Bui et al., 2020). Ramin et al. (2017) considered total assets and paid-up capital as a proxy of the size of the firms for the study and applied current and debt-equity ratio to measure the liquidity and solvency of the firm. They found that the correlation between solvency and total assets is positive and significant while solvency measured based on paidup capital is less significant and positive. Xu et al. (2019) revealed that the large firm's sales promotional activities positively govern the financial performance of the business. Shinde et al. (2013) found that the components of the capital structure in the Indian pharmaceutical sector vary from firm to firm. Ali (2020a) explored that the smaller Indian pharmaceutical firms are enjoying profitability more than the bigger firms with lower solvency. There is a between profitability and solvency. Ali (2020b) found that the firms' size determinants increase the absolute profits of the material sector companies of Saudi Arabia but not the profitability, proportionately. Ramya et al. (2014) advocated that the paying ability is also a measure of the financial performances of the business organizations. Some other studies reveal that financial performance and the paying ability of the firm is governed by some other factors. The R\& D (research and development) activities, patent level, and size of the firm define the level of export of the Indian pharmaceutical companies (Tyagi, \& Nauriyal, 2017). Viswanathan et al. (2016) and Palanisamy et al. (2015) explored that excess investment in current assets i.e. receivables and current stock is the cause of lower return while there is a positive and strong relationship between WC management and the strong financial position of the pharmaceutical companies in India. WC management is vital for the profitability of the pharmaceutical companies and it is also advantageous for owners' of the business (Chowdhury et al., 2018). Structural and physical capital affects the financial performances of Indian pharmaceutical companies' performances positively (Narwal, \& Ramandeep, 2014). There is a negative relationship between liquidity and profitability and the need to maintain the equilibrium between liquidity and profitability to enhance the paying ability goodwill of the business organization (Priya et al., 2013; Pushparaj Kulkarni et al., 2019). Panigrahi et al. (2018) also found a negative relationship between paying ability and profitability in Indian pharmaceutical companies and explored that all the liquid businesses need not suffering from low profitability. In further studies related to profitability and liquidity, Panigrahi et al. (2019) observed that profitability and liquidity relation are not similar in all companies of the same industry. There is a different opinion of Bhunia et al. (2015) that the profit earning capacity, WC management, and paying ability are not correlated mutually and revealed a weaker correlation among profitability, WC management, and payability. But, Srivastva (2017) found the profitability of Indian pharmaceutical industries is satisfactory.

\section{Materials and methods}

The study of the relationship between firm size determinants and solvency is based on the secondary data taken from the websites of the Indian pharmaceutical companies. The variables were taken from the financial statements of Sun Pharmaceutical Industries Limited (Su), Cipla Limited (Ci), Cadila Healthcare Limited (Ca), Aurobindo Pharma Limited (Ar), Dr. Reddy's Laboratories (Dr), and Lupin limited (Lu), Glenmark Pharma Limited (Gl) pharmaceutical companies to study the relationship of firm's size determinants and solvency or financial soundness. The average absolute amounts form the financial statements are to be used to determine the size of the Indian pharmaceutical companies, relatively. The average ranks of three proxies i.e. Total Assets (TA), Working Capital (WC), and sales revenue are used to determine the size of the selected Indian pharmaceutical companies. The working capital is the excess of Current Assets (CA) over current liabilities (CL) in the business organization (Ali, 2020c).

\section{Table 1}

Size \& Rankings of the leading selected Indian pharmaceutical companies

\begin{tabular}{|c|c|c|c|c|c|c|c|}
\hline \multirow[b]{2}{*}{ Size Determinants } & \multicolumn{4}{|c|}{ Indian pharmaceutical companies } & \multicolumn{2}{|c|}{ (Rs. in Million) } & \multirow[b]{2}{*}{ Gl } \\
\hline & $\mathrm{Su}$ & $\mathrm{Lu}$ & Dr & $\mathrm{Ci}$ & $\mathrm{Ar}$ & $\mathrm{Ca}$ & \\
\hline TA & 464474 & 179864 & 187476 & 176201 & 137885 & 112850 & 97422 \\
\hline R1 & 1 & 3 & 2 & 4 & 5 & 6 & 7 \\
\hline WC & 130960 & 55724 & 37184 & 41462 & 21521 & 7593 & 19358 \\
\hline $\mathrm{R} 2$ & 1 & 2 & 4 & 3 & 5 & 7 & 6 \\
\hline Sales & 241128 & 137190 & 142354 & 126912 & 120157 & 90097 & 72660 \\
\hline R3 & 1 & 3 & 2 & 4 & 5 & 6 & 7 \\
\hline Av. of Ranks & 1 & 2.67 & 2.67 & 3.67 & 5 & 6.33 & 6.67 \\
\hline Composite Rank & 1 & 2.5 & 2.5 & 4 & 5 & 6 & 7 \\
\hline
\end{tabular}

Source: Average absolute amounts of TA, WC, and sales are taken from the financial statements of the concerned companies for the period 2013-18.

Table 1 explains the size of the Indian pharmaceutical companies as per the size determinants i.e. TA, WC, and sales. Two different approaches are used to analyze the solvency of the selected Indian pharmaceutical companies.

Debt-Equity ratio $=\frac{L T D}{\text { Equity }}$

Debt to Total Assets Ratio $=\frac{L T D}{T A}$;

where, LTD = Long-Term Debts 
Debt-Equity ratio explains the solvency in respect to the ownership interest or against the capital of the owners of the business organization while the Debt to total assets ratio is the assurance of the redemption of the debts against the total resources of the business. The debt to total assets ratio is more favorable while the business is managing the funds from the internal sources and the debt-equity ratio is in case of management of funds from internal capital. In both cases, the solvency results would be stronger if the company were working on equity (Ali \& Haque, 2014). Spearman's rank correlation is calculated to get the relative correlation between the debt-equity ratios, debt to assets ratio, and size determinants of the firms.

Spearman's Rank Correlation $\left(\mathrm{r}_{\mathrm{s}}\right)=1-\frac{6 * \sum(D * D)}{n(n * n-1)}$

\section{Analysis and results}

The analysis of the relationship of the firm size and solvency of Indian pharmaceutical business organizations can be bifurcated into two i.e. industry analysis and firm analysis.

\subsection{Industry Analysis}

The industry analysis of the relationship of firm size and solvency status of Indian pharmaceutical reveal the co-movement or cohesiveness of the size determinants (sales, WC, and TA) and solvency agent proxies (LTD \& equity).

\subsubsection{Variability of Size determinants and solvency proxies}

The movement of an average of absolute size determinants and solvency proxies explain the cohesiveness and movement mutually. The similarity of the variances of variables of size determinants and solvency proxies will indicate the relationship and reflect the solvency status of the Indian pharmaceutical industry.

\section{Table 2}

Variability of absolute average amounts of size determinants (Sales, WC, and TA), and LTD \& Equity ( Rs. in Million) of Indian pharmaceutical companies

\begin{tabular}{|c|c|c|c|c|c|}
\hline Years & Sales & WC & TA & LTD & Equity \\
\hline 2,013 & 84,662 & 30,656 & 109,228 & 11,734 & 178,696 \\
\hline 2,014 & 105,068 & 39,773 & 135,885 & 11,666 & 205,730 \\
\hline 2,015 & 136,207 & 43,919 & 181,115 & 12,475 & 233,904 \\
\hline 2,016 & 149,810 & 50,150 & 219,349 & 22,594 & 264,137 \\
\hline 2,017 & 161,245 & 50,135 & 248,602 & 29,684 & 298,051 \\
\hline 2,018 & 160,577 & 54,341 & 268,256 & 31,763 & 331,889 \\
\hline Average & 132,928 & 44,829 & 193,739 & 19,986 & 252,068 \\
\hline$\sigma$ & 31,521 & 8,651 & 63,035 & 8,498 & 52,428 \\
\hline CV (\%) & 24 & 19 & 33 & 43 & 21 \\
\hline
\end{tabular}

Source: Yearly average absolute amounts of TA, WC, sales, LTD, and equity of all selected companies are taken from the financial statements for the period 2013-18.

Table 2 reveals that the variations of all variables are similar and indicates the cohesiveness except LTD. The movement in the average amounts of LTD abnormal and indicating the increasing trend since 2016. Overall, the variations of all variables (size determinants \& solvency proxies) are not statistically significant as the percentage of the co-efficient of the variation (CV) is below 100 .

\subsubsection{The relationship among size determinants solvency proxies}

Relationship of the size determinants and solvency proxies explain the average relationship and co-movement of the firm size and solvency variables. The stronger correlation among size determinants and solvency variables explain the symmetry and movement trend.

Table 3 explains that all size determinants and solvency proxies move together positively and strongly. It reveals that all the size determinants effects or govern positively. The variability and co-movement of the size determinants and solvency proxies reveal the normality of movement and expected relationship. The firm analysis will explain and divide the inferences based on the size and solvency of the Indian pharmaceutical companies. 
Table 3

Multiple correlation of average absolute size determinants (Sales, WC, and TA), and LTD \& Equity

\begin{tabular}{lccccc}
\hline & Sales & WC & TA & & \\
\hline Sales & 1 & & & \\
WC & 0.971 & 1 & 1 & \\
TA & 0.975 & 0.967 & 0.937 & 1 \\
LTD & 0.851 & 0.852 & 0.988 & 0.952 \\
Equity & 0.937 & 0.949 & 1 & \\
\hline
\end{tabular}

Source: Multiple correlation calculation is based upon the values given in the table 2 .

\subsection{Firm analysis}

The firm analysis considers the analysis of the business firms and extracts inferences relatively. The firm analysis of the Indian pharmaceutical companies analyzes the relationship of size determinants and solvency proxies generalize the inference of the study. Based on the solvency approach, the analysis can be divided into solvency based on ownership or owners' equity (debtequity ratio) and total resources (debt to total assets ratio).

\subsubsection{Solvency based on ownership or owners' equity}

Solvency based on ownership measures the relationship between the LTD and equity of the business organization. The lowest ratio of debt-equity is to be considered as the strongest indication of the solvency. The relative and qualitative correlation between the ranks of debt-equity ratio and size determinants explain the average relationship of solvency and size of the firm.

Table 4

Debt-Equity Ratio and rankings of Indian pharmaceutical companies (Rs. in Million)

\begin{tabular}{|c|c|c|c|c|c|c|c|c|c|c|c|c|}
\hline \multirow[b]{2}{*}{ Years } & \multicolumn{3}{|c|}{ Dr } & \multicolumn{3}{|c|}{$\mathrm{Lu}$} & \multicolumn{3}{|c|}{$\mathrm{Su}$} & \multicolumn{3}{|c|}{$\mathrm{Ci}$} \\
\hline & Debt & Equity & Ratio & Debt & Equity & Ratio & Debt & Equity & Ratio & Debt & Equity & Ratio \\
\hline 2013 & 12,659 & 63,691 & 0.199 & 11,645 & 52,042 & 0.224 & 1,153 & 149,897 & 0.008 & N.A. & 901,868 & 0.000 \\
\hline 2014 & 20,755 & 78,652 & 0.264 & 6,537 & 69,316 & 0.094 & 487 & 185,250 & 0.003 & 3,179 & $1,005,035$ & 0.032 \\
\hline 2015 & 14,315 & 98,531 & 0.145 & 5,371 & 91,732 & 0.059 & 13,684 & 256,232 & 0.053 & 3,093 & $1,078,924$ & 0.029 \\
\hline 2016 & 10,690 & 117,009 & 0.091 & 71,775 & 111,634 & 0.643 & 31,167 & 314,042 & 0.099 & 2,219 & $1,151,622$ & 0.019 \\
\hline 2017 & 5,449 & 122,621 & 0.044 & 79,661 & 134,976 & 0.590 & 14,361 & 366,397 & 0.039 & 36,454 & $1,252,542$ & 0.291 \\
\hline 2018 & 25,089 & 125,716 & 0.200 & 71,428 & 135,771 & 0.526 & 17,721 & 381,006 & 0.047 & 36,621 & $1,422,919$ & 0.257 \\
\hline Av. & & & 0.157 & & & 0.356 & & & 0.041 & & & 0.105 \\
\hline Ranks & & & 3 & & & 6 & & & 1 & & & 2 \\
\hline
\end{tabular}

Source: Amounts of debt and equity are taken from the financial statements of the concerned companies

\section{Table 4}

Debt-Equity Ratio and rankings of Indian pharmaceutical companies (Rs. in Million) (Continued)

\begin{tabular}{|c|c|c|c|c|c|c|c|c|c|}
\hline \multirow[b]{2}{*}{ Years } & \multicolumn{3}{|c|}{$\mathrm{Ar}$} & \multicolumn{3}{|c|}{$\mathrm{Ca}$} & \multicolumn{3}{|c|}{ Gl } \\
\hline & Debt & Equity & Ratio & Debt & Equity & Ratio & Debt & Equity & Ratio \\
\hline 2013 & 11,483 & 26,058 & 0.441 & 14,260 & 29,445 & 0.484 & 19,203 & 27,874 & 0.689 \\
\hline 2014 & 12,794 & 37,502 & 0.341 & 13,622 & 34,390 & 0.396 & 24,287 & 29,966 & 0.810 \\
\hline 2015 & 13,615 & 51,559 & 0.264 & 11,504 & 42,516 & 0.271 & 25,744 & 17,835 & 1.443 \\
\hline 2016 & 8,472 & 70,567 & 0.120 & 8,964 & 53,519 & 0.167 & 24,873 & 30,564 & 0.814 \\
\hline 2017 & 1,814 & 93,740 & 0.019 & 24,684 & 71,161 & 0.347 & 45,363 & 44,921 & 1.010 \\
\hline 2018 & 4,512 & 116,822 & 0.039 & 25,551 & 89,355 & 0.286 & 41,418 & 51,631 & 0.802 \\
\hline Av. & & & 0.204 & & & 0.325 & & & 0.928 \\
\hline Ranks & & & 4 & & & 5 & & & 7 \\
\hline
\end{tabular}

Table 4 explains that the owners' equity point of view the solvency of the $\mathrm{Su}, \mathrm{Ci}$, Dr, and Ar is satisfactory while Gl, Ca, and $\mathrm{Lu}$ are weaker, relatively. The relative correlation of the debt-equity and firm size determinants (sales, TA, and WC) ranks will explain the relationship of debt-equity ratio with each size determinants, individually.

\section{Table 5}

Qualitative relationship between Total assets and Debt- Equity relationship of Indian Pharmaceutical firms

\begin{tabular}{|c|c|c|c|c|c|c|c|c|c|c|}
\hline \multirow[b]{2}{*}{ Ranks } & \multicolumn{10}{|c|}{ Indian pharmaceutical companies } \\
\hline & $\mathrm{Su}$ & $\mathrm{Lu}$ & & Dr & & & $\mathrm{Ar}$ & $\mathrm{Ca}$ & Gl & \\
\hline Total Assets (R1) & & & 3 & & 2 & 4 & 5 & 6 & 7 & \\
\hline Debt-Equity (R2) & & & 6 & & 3 & 2 & 4 & 5 & 7 & \\
\hline $\mathrm{D}(\mathrm{R} 1-\mathrm{R} 2)$ & & & -3 & & -1 & 2 & 1 & 1 & 0 & \\
\hline $\mathrm{D}^{2}$ & & & 9 & & 1 & 4 & 1 & 1 & 0 & $\sum \mathrm{D}^{2}=16$ \\
\hline
\end{tabular}

Originating Source: R1 and R2 from table 1 and 4. 
Spearman's Rank Correlation $\left(\mathrm{r}_{\mathrm{s}}\right)=1-\frac{6 * \sum(D * D)}{n(n * n-1)} ; \quad=1-\frac{6 * 16}{7(7 * 7-1)} ; \quad=0.71$

Table 5 explains that the qualitative relationship between debt-equity and total assets is positive and moderate (0.71). The level of total resources moderately correlated with the debt-equity ratio or the TA of the Indian pharmaceutical companies positively and moderately governs the solvency owners' point of view.

Table 6

Qualitative relationship between WC and Debt- Equity relationship of Indian Pharmaceutical firms

\begin{tabular}{|c|c|c|c|c|c|c|c|c|}
\hline \multirow[b]{2}{*}{ Ranks } & \multicolumn{7}{|c|}{ Indian pharmaceutical companies } & \\
\hline & $\mathrm{Su}$ & $\mathrm{Lu}$ & Dr & $\mathrm{Ci}$ & $\mathrm{Ar}$ & $\mathrm{Ca}$ & Gl & \\
\hline WC (R1) & 1 & 2 & 4 & 3 & 5 & 7 & 6 & \\
\hline Debt-Equity (R2) & 1 & 6 & 3 & 2 & 4 & 5 & 7 & \\
\hline $\mathrm{D}(\mathrm{R} 1-\mathrm{R} 2)$ & 0 & -4 & 1 & 1 & 1 & 2 & -1 & \\
\hline $\mathrm{D}^{2}$ & 0 & 16 & 1 & 1 & 1 & 4 & 1 & $\sum \mathrm{D}^{2}=24$ \\
\hline
\end{tabular}

Originating Source: R1 and R2 from Table 1 and Table 4.

Spearman's Rank Correlation $\left(\mathrm{r}_{\mathrm{s}}\right)=1-\frac{6 * \sum(D * D)}{n(n * n-1)}=1-\frac{6 * 24}{7(7 * 7-1)}=0.57$

From Table 6, it can be explained that the qualitative relationship between debt-equity and WC is positive and moderate (0.57). The amount of WC moderately correlated with the debt-equity ratio or the WC of the Indian pharmaceutical companies positively and moderately governs the solvency owners' point of view.

\section{Table 7}

Qualitative relationship between Sales and Debt- Equity relationship of Indian Pharmaceutical firms

\begin{tabular}{|c|c|c|c|c|c|c|c|c|}
\hline & & & arma & $1 \mathrm{co}$ & ies & & & \\
\hline Ranks & $\mathrm{Su}$ & $\mathrm{Lu}$ & Dr & $\mathrm{Ci}$ & $\mathrm{Ar}$ & $\mathrm{Ca}$ & Gl & \\
\hline Sales (R1) & 1 & 3 & 2 & 4 & 5 & 6 & 7 & \\
\hline Debt-Equity (R2) & 1 & 6 & 3 & 2 & 4 & 5 & 7 & \\
\hline $\mathrm{D}(\mathrm{R} 1-\mathrm{R} 2)$ & 0 & -3 & -1 & 2 & 1 & 1 & 0 & \\
\hline $\mathrm{D}^{2}$ & 0 & 9 & 1 & 4 & 1 & 1 & 0 & $\sum \mathrm{D}^{2}=16$ \\
\hline
\end{tabular}

Originating Source: R1 and R2 from table 1 and 4.

Spearman's Rank Correlation $\left(\mathrm{r}_{\mathrm{s}}\right)=1-\frac{6 * \sum(D * D)}{n(n * n-1)}=1-\frac{6 * 16}{7(7 * 7-1)}=0.71$

From Table 7, it can be explained that the qualitative relationship between debt-equity and sales is positive and moderate (0.71). The amount of sales moderately correlated with the debt-equity ratio or the sales amount of the Indian pharmaceutical companies positively and moderately governs the solvency owners' point of view.

Table 8

Rank correlation between averages of size determinants ranks and Debt- equity ratio

\begin{tabular}{|c|c|c|c|c|c|c|c|c|}
\hline \multirow[b]{2}{*}{ Ranks } & \multicolumn{7}{|c|}{ Indian pharmaceutical companies } & \\
\hline & $\mathrm{Su}$ & $\mathrm{Lu}$ & Dr & $\mathrm{Ci}$ & $\mathrm{Ar}$ & $\mathrm{Ca}$ & Gl & \\
\hline Size det. (R1) & 1 & 2.5 & 2.5 & 4 & 5 & 6 & 7 & \\
\hline Debt-Equity (R2) & 1 & 6 & 3 & 2 & 4 & 5 & 7 & \\
\hline $\mathrm{D}(\mathrm{R} 1-\mathrm{R} 2)$ & 0 & -3.5 & -0.5 & 2 & 1 & 1 & 0 & \\
\hline $\mathrm{D}^{2}$ & 0 & 12.3 & 0.3 & 4 & 1 & 1 & 0 & $\sum \mathrm{D}^{2}=18.50$ \\
\hline
\end{tabular}

Originating Source: R1 and R2 from Table 1 and Table 4.

Spearman's Rank Correlation $\left(\mathrm{r}_{\mathrm{s}}\right)=1-\frac{6 * \sum(D * D)}{n(n * n-1)}=1-\frac{6 * 18.50}{7(7 * 7-1)}=0.67$

Table 8 concludes that the qualitative relationship between debt-equity and size determinants is positive and moderate (0.67). The amount of size determinants moderately correlated with the debt-equity ratio or the size determinants of the Indian pharmaceutical companies positively and moderately governs the solvency owners' point of view. The relationship of WC (0.57) with the debt-equity ratio is positive but weaker than the TA (0.71) and sales (0.71) of the Indian pharmaceutical companies. 


\subsubsection{Solvency based on total assets (TA) or total resources}

Solvency based on ownership measures the relationship between the LTD and TA of the business organization. The lowest ratio of debt-TA is to be considered as the strongest indication of the solvency. The relative qualitative correlation between the ranks of debt- TA ratio and size determinants explain the average relationship of solvency and size of the firm.

Table 9

Debt-TA Ratio and rankings of Indian pharmaceutical companies

\begin{tabular}{|c|c|c|c|c|c|c|c|c|c|c|c|c|}
\hline \multirow[b]{2}{*}{ Years } & \multicolumn{3}{|c|}{$\mathrm{Dr}$} & \multicolumn{3}{|c|}{$\mathrm{Lu}$} & \multicolumn{3}{|c|}{$\mathrm{Su}$} & \multicolumn{3}{|c|}{$\mathrm{Ci}$} \\
\hline & Debt & TA & Ratio & Debt & TA & Ratio & Debt & TA & Ratio & Debt & TA & Ratio \\
\hline 2013 & 12,659 & 134,872 & 0.094 & 11,645 & 89,139 & 0.131 & 1,153 & 205,827 & 0.006 & & 11,658 & 0 \\
\hline 2014 & 20,755 & 160,296 & 0.129 & 6,537 & 102,060 & 0.064 & 487 & 293,708 & 0.002 & 318 & 13,403 & 0.024 \\
\hline 2015 & 14,315 & 185,978 & 0.077 & 5,371 & 132,610 & 0.041 & 13,684 & 487,985 & 0.028 & 309 & 15,718 & 0.02 \\
\hline 2016 & 10,690 & 200,104 & 0.053 & 71,775 & 226,249 & 0.317 & 31,167 & 542,196 & 0.057 & 222 & 21,128 & 0.011 \\
\hline 2017 & 5,449 & 218,165 & 0.025 & 79,661 & 266,073 & 0.299 & 14,361 & 614,102 & 0.023 & 3,645 & 20,953 & 0.174 \\
\hline 2018 & 25,089 & 225,443 & 0.111 & 71,428 & 263,054 & 0.272 & 17,721 & 643,028 & 0.028 & 3,662 & 22,861 & 0.16 \\
\hline Av. & & & 0.082 & & & 0.187 & & & 0.024 & & & 0.065 \\
\hline Ranks & & & 4 & & & 6 & & & 1 & & & 2 \\
\hline
\end{tabular}

Source: Amounts of debt and equity are taken from the financial statements of the concerned companies.

Table 9

Debt-TA Ratio and rankings of Indian pharmaceutical companies

\begin{tabular}{|c|c|c|c|c|c|c|c|c|c|}
\hline \multirow[b]{2}{*}{ Years } & \multicolumn{3}{|c|}{$\mathrm{Ar}$} & \multicolumn{3}{|c|}{$\mathrm{Ca}$} & \multicolumn{3}{|c|}{$\mathrm{Gl}$} \\
\hline & Debt & TA & Ratio & Debt & TA & Ratio & Debt & TA & Ratio \\
\hline 2013 & 11,483 & 72,729 & 0.158 & 14,260 & 73,742 & 0.193 & 19,203 & 71,710 & 0.268 \\
\hline 2014 & 12,794 & 94,898 & 0.135 & 13,622 & 79,865 & 0.171 & 24,287 & 86,336 & 0.281 \\
\hline 2015 & 13,615 & 129,145 & 0.105 & 11,504 & 90,471 & 0.127 & 25,744 & 84,439 & 0.305 \\
\hline 2016 & 8,472 & 156,994 & 0.054 & 8,964 & 100,163 & 0.089 & 24,873 & 98,454 & 0.253 \\
\hline 2017 & 1,814 & 162,494 & 0.011 & 24,684 & 152,207 & 0.162 & 45,363 & 117,639 & 0.386 \\
\hline 2018 & 4,512 & 211,052 & 0.021 & 25,551 & 180,653 & 0.141 & 41,418 & 125,954 & 0.329 \\
\hline Av. & & & 0.081 & & & 0.147 & & & 0.304 \\
\hline Ranks & & & 3 & & & 5 & & & 7 \\
\hline
\end{tabular}

Table 9 explains that the total assets point of view the solvency of the $\mathrm{Su}, \mathrm{Ci}, \mathrm{Dr}$, and $\mathrm{Ar}$ are satisfactory while $\mathrm{Gl}$, $\mathrm{Ca}$, and $\mathrm{Lu}$ is weaker, relatively. The relative correlation of the debt- TA ranks and firm size determinants (sales, TA, and WC) will explain the relationship of debt-equity ratio with each size determinants, individually.

\section{Table 10}

Qualitative relationship between Total assets and Debt- TA relationship of Indian Pharmaceutical firms

\begin{tabular}{|c|c|c|c|c|c|c|c|}
\hline \multirow[b]{2}{*}{ Ranks } & \multicolumn{7}{|c|}{ Indian pharmaceutical companies } \\
\hline & $\mathrm{Su}$ & $\mathrm{Lu}$ & Dr & $\mathrm{Ci}$ & $\mathrm{Ar}$ & $\mathrm{Ca}$ & Gl \\
\hline Total Assets (R1) & 1 & 3 & 2 & 4 & 5 & 6 & 7 \\
\hline Debt-TA (R2) & 1 & 6 & 4 & 2 & 3 & 5 & 7 \\
\hline $\mathrm{D}(\mathrm{R} 1-\mathrm{R} 2)$ & 0 & -3 & -2 & 2 & 2 & 1 & 0 \\
\hline $\mathrm{D}^{2}\left(\sum \mathrm{D}^{2}=22\right)$ & 0 & 9 & 4 & 4 & 4 & 1 & 0 \\
\hline
\end{tabular}

Originating Source: R1 and R2 from Table 1 and Table 9.

Spearman's Rank Correlation $\left(\mathrm{r}_{\mathrm{s}}\right)=1-\frac{6 * \sum(D * D)}{n(n * n-1)}=1-\frac{6 * 22}{7(7 * 7-1)}=0.61$

From Table 10, it can be explained that the qualitative relationship between debt-TA ratio and TA is positive and moderate (0.61). The level of total resources moderately correlated with the debt-TA ratio or the TA of the Indian pharmaceutical companies positively and moderately governs the solvency against total assets.

Table 11

Qualitative relationship between WC and Debt- TA relationship of Indian Pharmaceutical firms

\begin{tabular}{|c|c|c|c|c|c|c|c|}
\hline \multirow[b]{2}{*}{ Ranks } & \multicolumn{7}{|c|}{ Indian pharmaceutical companies } \\
\hline & $\mathrm{Su}$ & $\mathrm{Lu}$ & Dr & $\mathrm{Ci}$ & $\mathrm{Ar}$ & $\mathrm{Ca}$ & Gl \\
\hline WC (R1) & 1 & 2 & 4 & 3 & 5 & 7 & 6 \\
\hline Debt-TA (R2) & 1 & 6 & 4 & 2 & 3 & 5 & 7 \\
\hline $\mathrm{D}(\mathrm{R} 1-\mathrm{R} 2)$ & 0 & -4 & 0 & 1 & 2 & 2 & -1 \\
\hline $\mathrm{D}^{2}\left(\sum \mathrm{D}^{2}=26\right)$ & 0 & 16 & 0 & 1 & 4 & 4 & 1 \\
\hline
\end{tabular}

Originating Source: R1 and R2 from Table 1 and Table 9. 
Spearman's Rank Correlation $\left(\mathrm{r}_{\mathrm{s}}\right)=1-\frac{6 * \sum(D * D)}{n(n * n-1)}=1-\frac{6 * 26}{7(7 * 7-1)}=0.54$

From Table 11, it can be explained that the qualitative relationship between debt-TA ratio and WC is positive and moderate (0.54). The amount of WC moderately correlated with the debt-TA ratio or the WC of the Indian pharmaceutical companies positively and moderately governs the solvency against total assets.

Table 12

Qualitative relationship between Sales and TA relationship of Indian Pharmaceutical firms

\begin{tabular}{|c|c|c|c|c|c|c|c|}
\hline \multirow[b]{2}{*}{ Ranks } & \multicolumn{7}{|c|}{ Indian pharmaceutical companies } \\
\hline & $\mathrm{Su}$ & $\mathrm{Lu}$ & $\mathrm{Dr}$ & $\mathrm{Ci}$ & $\mathrm{Ar}$ & $\mathrm{Ca}$ & Gl \\
\hline Sales (R1) & 1 & 3 & 2 & 4 & 5 & 6 & 7 \\
\hline Debt-TA (R2) & 1 & 6 & 4 & 2 & 3 & 5 & 7 \\
\hline $\mathrm{D}(\mathrm{R} 1-\mathrm{R} 2)$ & 0 & -3 & -2 & 2 & 2 & 1 & 0 \\
\hline $\mathrm{D}^{2}\left(\sum \mathrm{D}^{2}=22\right)$ & 0 & 9 & 4 & 4 & 4 & 1 & 0 \\
\hline
\end{tabular}

Originating Source: R1 and R2 from Table 1 and Table 9.

Spearman's Rank Correlation $\left(\mathrm{r}_{\mathrm{s}}\right)=1-\frac{6 * \sum(D * D)}{n(n * n-1)}=1-\frac{6 * 22}{7(7 * 7-1)}=0.61$

From Table 12, it can be explained that the qualitative relationship between debt-TA ratio and sales is positive and moderate (0.61). The amount of sales moderately correlated with the debt-TA ratio or the sales amount of the Indian pharmaceutical companies positively and moderately governs the solvency against total assets.

Table 13

Rank correlation between averages of size determinants ranks and Debt- TA ratio

\begin{tabular}{|c|c|c|c|c|c|c|c|}
\hline \multirow[b]{2}{*}{ Ranks } & \multicolumn{7}{|c|}{ Indian pharmaceutical companies } \\
\hline & $\mathrm{Su}$ & $\mathrm{Lu}$ & Dr & $\mathrm{Ci}$ & $\mathrm{Ar}$ & $\mathrm{Ca}$ & Gl \\
\hline Size det. (R1) & 1 & 2.5 & 2.5 & 4 & 5 & 6 & 7 \\
\hline Debt-TA (R2) & 1 & 6 & 4 & 2 & 3 & 5 & 7 \\
\hline $\mathrm{D}(\mathrm{R} 1-\mathrm{R} 2)$ & 0 & -3.5 & -1.5 & 2 & 2 & 1 & 0 \\
\hline $\mathrm{D}^{2}\left(\sum \mathrm{D}^{2}=23.50\right)$ & 0 & 12.25 & 2.25 & 4 & 4 & 1 & 0 \\
\hline
\end{tabular}

Originating Source: R1 and R2 from Table 1 and Table 9.

Spearman's Rank Correlation $\left(\mathrm{r}_{\mathrm{s}}\right)=1-\frac{6 * \sum(D * D)}{n(n * n-1)}=1-\frac{6 * 23.50}{7(7 * 7-1)}=0.58$

Table 13 concludes that the qualitative relationship between debt-TA and size determinants is positive and moderate (0.58). The amount of size determinants moderately correlated with the debt-TA ratio or the size determinants of the Indian pharmaceutical companies positively and moderately governs the solvency against the total assets. The relationship of WC with debt-equity ratio $(0.54)$ is positive but weaker than the TA $(0.61)$ and sales $(0.61)$ of the Indian pharmaceutical companies.

\subsubsection{Debt-equity ratio, debt-TA, and size determinants of Indian pharmaceutical companies}

Consolidated study of the debt-equity ratio, debt-TA, and size determinants explain the average relation of size determinants and solvency of Indian pharmaceutical companies.

Table 14

Summary of qualitative correlation between size determinants and solvency

\begin{tabular}{|c|c|c|c|c|}
\hline \multirow[t]{2}{*}{ Ratio } & \multicolumn{4}{|c|}{ Correlation of ranks of size determinants and debt-equity, debt-TA ratio } \\
\hline & TA & WC & Sales & Size det. \& sol. proxies \\
\hline Debt-equity & 0.71 & 0.57 & 0.71 & 0.67 \\
\hline Debt-TA & 0.61 & 0.58 & 0.61 & 0.58 \\
\hline
\end{tabular}

Originating source: Rank Correlation co-efficient from the table 4 and 9.

From the concluding Table 14, it is obvious that the average relationship between size determinants and solvency proxies are positive and moderate. The solvency against ownership (0.67) is comparatively more strongly governed by the solvency against the total resources (0.58). There is similarity in solvency against the size determinants TA (0.71) and sales (0.61) for ownership and total point of view. The solvency difference of the WC size determinants against the ownership and total resources is against is insignificant $(0.57$ and 0.58$)$. 


\section{Discussion}

There are few studies available explaining the relationship of size determinants and the solvency proxies. Mutiara et al. (2018) and Lopez-Valeiras et al. (2016) observed in their studies that the firm's size has negatively governed the financial performance and financial soundness. But, the relative study of Indian pharmaceutical companies explains that there is a positive qualitative relationship between the size determinants and solvency proxies. The relation of firm size and solvency proxies is stronger as per solvency against the ownership comparatively solvency against total resources. This implies that companies have to issue more equity capital to make financially sound. But, excess of equity capital will diminish the expected return on existing owners' capital, and companies will not be able to enjoy the benefits of working on equity (González \& González, 2011). The WC size determinant $(0.57,0.58)$ governs the solvency but not so strongly as TA $(0.71,0.61)$ and sales $(0.71,0.61)$ of the Indian pharmaceutical companies for owners' capital and total assets point of view. There is similarity seen in the relationship of TA, sales, and solvency of the Indian pharmaceutical companies.

\section{Conclusion}

Based on the above all industry and firm analysis, it can be concluded that the size determinants of the Indian pharmaceutical companies positively and moderately govern the solvency or financial soundness to redeem its long-term debts (LTDs). In the relative study, the size determinants govern positively and strongly the ownership solvency (debt-equity) comparatively solvency total resources or total assets point of view. To enhance the solvency of the Indian pharmaceutical companies, there is a need to issue the equity capital to arrange the TA of the business organization. But the equity capital cannot be issued up to a certain limit to provide the progressive return on existing equity capital. The solvency situation in the bigger pharmaceutical organization is better than the smaller business organization in India. Probably, the bigger organizations manage the total resources from their internal funds or owners' equity. In a smaller pharmaceutical organization in India manage the maximum of their total resources from the external funds and enjoy the benefits of the working on equity. WC of the Indian pharmaceutical companies govern and has a lower impact on solvency indirectly. So, there is a need to enhance the owners' equity in the smaller pharmaceutical organization of India to make them financially sound to payout their LTDs. Inversely, the bigger Indian pharmaceutical companies may enhance their LTD to enjoy the benefits of working on equity as their solvency to pay out their LTD. Overall, the solvency of all Indian pharmaceutical companies either satisfactory in smaller Indian pharmaceutical companies or robust in the bigger Indian pharmaceutical organization. The study only considers only the absolute amount of the equity, TA, and LTD of the Indian pharmaceutical organization while there is a need to consider the salability or maturity of the ingredients of TA according to the redemption tenure of the LTDs. There is scope for further researches to analyze in-depth the relationship of size and solvency of the Indian pharmaceutical companies after considering the scheduled payment of the LTDs and availability of the resources of TA to payout the scheduled redemptions.

\section{References}

Ali. A. (2020a). Do the giant players enjoy profitability? Analytical study of Pharmaceutical Industry of India. Talent Development \& Excellence, $12(2 \mathrm{~s}), 3249-3260$.

Ali. A. (2020b). Does size affect financial performance? Absolute and relative analysis of materials sector companies of Saudi Arabia. Journal of Critical Reviews, 7(15), 212-220.

Ali, A. (2020c). Working capital, profit and profitability: An absolute and relational study of selected leading Indian pharmaceutical firms. Accounting, 6(6), 951-960.

Ali. A., Haque, M.I. (2014). Ratio Analysis: A Comparative Study of National Petrochemicals Co. and Sahara Petrochemicals Co. of Saudi Arabia. International Journal of Management Academy, 2(4), 53-61.

Ayuba, H., Bambale, A. J., Ibrahim, M. A., \& Sulaiman, S. A. (2019). Effects of financial performance, capital structure and firm size on firms' value of insurance companies in Nigeria. Journal of Finance, Accounting and Management, 10(1), 5774.

Bhunia, A., \& Das, A. (2015). Underlying relationship between working capital management and profitability of pharmaceutical companies in India. American Journal of Theoretical and Applied Business, 1(1), 27-36.

Bui, H., Nguyen, D., Tran, D., Hoang, P., Pham, M., \& Tran, M. (2020). Determinants influencing the profitability of listed food processing firms in Vietnam. Accounting, 6(4), 441-452.

Chowdhury, A. Y., Alam, M. Z., Sultana, S., \& Hamid, M. K. (2018). Impact of working capital management on profitability: A case study on pharmaceutical companies of Bangladesh. Journal of Economics, Business and Management, 6(1), 27-35.

Dang, C., Li, Z. F., \& Yang, C. (2018). Measuring firm size in empirical corporate finance. Journal of Banking \& Finance, 86, 159-176.

González, V. M., \& González, F. (2011). Firm size and capital structure: Evidence using dynamic panel data. Applied Economics, 44(36), 4745-4754.

Huff, P. L., Harper Jr, R. M., \& Eikner, A. E. (1999). Are there differences in liquidity and solvency measures based on company size?. American Business Review, 17(2), 96-106. 
Lopez-Valeiras, E., Gomez-Conde, J., \& Fernandez-Rodriguez, T. (2016). Firm size and financial performance: intermediate effects of indebtedness. Agribusiness, 32(4), 454-465.

Marjohan, M., \& Sarwani, H. (2019). The analysis of the effect of intellectual capital, company growth, size, solvency on profitability and their impact on company value. In Proceeding Interuniversity Forum for Strengthening Academic Competency, 1(1), 53-60.

Muhindi, K. A., \& Ngaba, D. (2018). Effect of firm size on financial performance on banks: Case of commercial banks in Kenya. International Academic Journal of Economics and Finance, 3(1), 175-190.

Mutiara, Y. T., Zakaria, A., \& Anggraini, R. (2018). The influence of company size, company profit, solvency and CPA firm size on audit report lag. Journal of Economics Finance and Accounting, 5(1), 1-10.

Nair, J. (2013). Performance analysis and solvency prediction of Indian pharma companies. International Journal of Marketing, Financial Services \& Management Research, 2(5), 34-43.

Narwal, K. P., \& Ramandeep (2014). The Relationship between intellectual capital and financial performance: An empirical study of Indian pharmaceutical industry. MERC Global's International Journal of Management, 2(4), 151-169.

Palanisamy, A., \& Sengottaiyan, A. (2015). Analysis of working capital position of selected pharmaceutical companies in India. International Journal in Management \& Social Science, 3(8), 97-106.

Panigrahi, C. M. A. (2019). Liquidity and Profitability Relationship and Financial Fallacy. Think India Journal, 22(10). 704718.

Panigrahi, C. M. A., Raul, N., \& Gijare, C. (2018). Liquidity and profitability trade-off: A study of Indian pharmaceutical companies. NMIMS Journal of Economics and Public Policy, 3(1). 42-56.

Priya, K., \& Nimalathasan, B. (2013). Liquidity management and profitability: A case study of listed manufacturing companies in Sri Lanka. International Journal of Technological Exploration and Learning, 2(4), 161-165.

Pushparaj Kulkarni, D., \& Pimplapure, V. (2019). An analytical study of profitability of pharmaceutical companies in India. Journal of the Gujarat Research Society, 21(16), 50-57.

Ramin, A. K., Lizam, M., Zabri, S. M., \& Ahmad, M. F. (2017). Firm's size and solvency performance: Evidence from the Malaysian public listed firms. Journal of Engineering and Applied Sciences, 12(5), 1240-1244.

Ramya, A., \& Sekar, M. (2014). Study on financial analysis of selected Indian pharmaceutical companies. Research Journali's Journal of Commerce, 2(5), 1-12.

Saragih, M. R. (2019). The effect of company size, solvency and audit committee on delay audit. SCIENTIFIC JOURNAL OF REFLECTION: Economic, Accounting, Management and Business, 2(2), 191-200.

Shinde, C. M., \& Adhegaonkar, V. R. (2013). Capital structure behavior with size of business-A case of Indian pharmaceutical industry. International Journal of Management, IT and Engineering, 3(9), 427-438.

Srivastva, A. (2017). Diagnosing Inter Firm Profitability of Pharmaceutical Industry: An Empirical Analysis for India. IJCRR, 9(9), 32-36. DOI: http://dx.doi.org/10.7324/IJCRR.2017.993236

Tyagi, S., \& Nauriyal, D. K. (2017). Firm level profitability determinants in Indian drugs and pharmaceutical industry. International Journal of Pharmaceutical and Healthcare Marketing, 11(3), 271290.

Viswanathan, D., Palanisamy, D., \& Mahesh, R. (2016). A comparative study on working capital management of selected pharmaceutical companies in India. Social Sciences, 3(3), 499-511.

Xu, J., Liu, F., \& Chen, Y. H. (2019). R\&D, Advertising and Firms' Financial Performance in South Korea: Does Firm Size Matter?. Sustainability, 11(14), 3764.

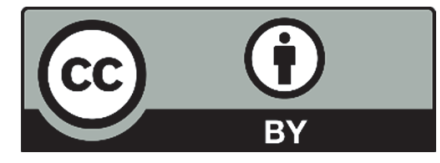

(C) 2020 by the authors; licensee Growing Science, Canada. This is an open access article distributed under the terms and conditions of the Creative Commons Attribution (CC-BY) license (http://creativecommons.org/licenses/by/4.0/). 